НАУКОВИЙ ВІСНИК

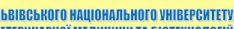

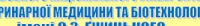
entific secentific messenger of Liviv National University of
veterinary Medicine and Biotechnologies

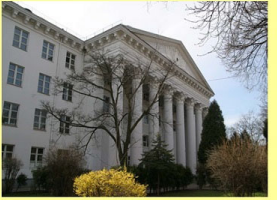

СЕРІІ "ЕКОНОМІчН НАУК'

Том 22 № 95 2020

Науковий вісник Аьвівського національного університету ветеринарної медицини та біотехнологій імені С.3. Гжицького. Серія: Економічні науки

\author{
Scientific Messenger of Lviv National University \\ of Veterinary Medicine and Biotechnologies. \\ Series: Economical Sciences
}

UDC 636:631(471)4

\title{
Analysis of the ratio of livestock and livestock production by farms of Lviv region at the turn of the century
}

\author{
M. Shulskyi \\ Stepan Gzhytskyi National University of Veterinary Medicine and Biotechnologies Lviv, Ukraine
}

Article info

Received 03.09.2020

Received in revised form 05.10 .2020

Accepted 06.10.2020

Stepan Gzhytskyi National University of Veterinary Medicine and Biotechnologies Lviv,

Pekarska Str., 50, Lviv, 79010, Ukraine.

Tel.: +38-097-569-77-12

E-mail:Pretty62@ukr.net
Shulskyi, M. (2020). Analysis of the ratio of livestock and livestock production by farms of Lviv region at the turn of the century. Scientific Messenger of Lviv National University of Veterinary Medicine and Biotechnologies. Series: Economical Sciences, 22(95), 32-37. doi: 10.32718/nvlvete9506

The end of the $X X$ and the beginning of the XXI centuries were characterized by radical changes in all spheres of social relations. During this period there was an intensive process of breaking the socialist systems of economic activity and the transition to a market economy. These changes can be fully attributed to the epoch-making, because there have been radical changes in all components of various spheres of social relations. Regarding the digital information used in the analysis of the presence of livestock in farms of Lviv region, it is reasonable to say that during the study period significantly decreased the number of farm animals in all categories of farms and in terms of enterprises and households. Regarding the indicators of livestock production in economic entities of Lviv region, the situation here is almost similar in terms of changes in the number of farm animals. The essence of the problem of this study is to analyze the effects of economic processes on the state of livestock development in Lviv region. At the same time, we have selected the main components of the functioning of the industry, namely: the presence of livestock and the volume of livestock production. These indicators are important and form the basis of the industry and therefore they are chosen as the basis that forms the essence of the problem. Our research should encourage scientists to conduct further research on the state of development of animal husbandry with a focus on identifying the causes that inhibited and inhibit the effective functioning of the livestock industry. The obtained research results should become an effective basis for managers and specialists to make rational management decisions to eliminate certain inhibitory factors in the development of animal husbandry.

Key words: analysis, livestock industries, livestock, production, products, enterprise, households.

\section{Аналіз співвідношення поголів'я сільськогосподарських тварин і виробництва тваринницької продукції господарствами Львівщини на стику епох}

\author{
М. Г. Шульський
}

Львівський національний університет ветеринарної медицини та біотехнологій імені С. 3. Гљицького, м. Львів, Україна

Кінець XX і початок XXI століть характеризувався корінними змінами в усіх сферах суспільних відносин. У ией період відбувався інтенсивний процес ломки соиіалістичних систем ведення господарської діяльності і перехід до умов ринкової економіки. Ці зміни у повній мірі можна віднести до епохальних, адже відбулись кардинальні зміни в усіх складових різних сфер суспільних відносин. Щодо цифрової інформації, щчо використана при аналізі наявності поголів'я сільськогосподарських тварин у господарствах Львівщини, дають підстави стверджувати, щуо за досліджуваний період значно зменшилось поголів'я сільськогосподарських тварин як в усіх категоріях господарств, так і в розрізі підприємств та господарств населення. Відносно показників виробництва продукиії тваринництва у господарюючих суб 'єктів Львівщчини то тут ситуація майже аналогічна щзодо зміни поголів'я сільськогосподарських тварин. Суть проблеми даного дослідження полягає в тому, шуоб проаналізувати наслідки впливу економічних про- 
цеесів на стан розвитку тваринництва Львівської області. При ирьому нами обрано основні складові функціонування галузі, а саме: наявність поголів'я сільськогосподарських тварин та обсяги виробництва продукції тваринництва. Зазначені показники є важливими та складають основу розвитку галузі і тому їх обрано за основу, шуо формує суть поставленої проблеми. Наші дослідження повинні спонукати науковців до проведення подальших досліджень стану розвитку тваринництва з концентрацією уваги на виявлення причин, шо гальмували і гальмують ефективне функиіонування тваринницьких галузей. Одержані результати досліджень повинні стати дієвою основою керівникам і спеціалістам для прийняття раціональних управлінських рішень щуодо усунення певних гальмівних чинників у розвитку тваринництва.

Ключові слова: аналіз, тваринницькі галузі, поголів'я сільськогосподарських тварин, виробництво, продукиія, підприємство, господарства населення.

\section{Вступ}

Постановка проблеми. Аналіз змін, що відбулись в кінці XX і на початку XXI століть, обумовили докорінне перетворення у різних сферах суспільних відносин. Особливо це відноситься до сфер виробництва взагалі і його важливою складовою АПК, а в ньому до основних галузей аграрного сектору економіки, серед яких важливе місце займає тваринництво. Ця галузь чи не найбільше зазнала негативних впливів реформуючих процесів на іiі розвиток. Саме із-за цих аспектів виникає насущна проблема дослідити, як перетворюючі процеси вплинули на стан функціонування галузі. Цей напрям наукових досліджень вимагає комплексного і, що важливо, об'єктивного та всебічного дослідження. Одночасно зауважимо, що у цій публікації із-за сторінкового обмеження викладу матеріалів неможливо висвітлити всі наявні проблеми, основні складові яких у тій чи тій мірі негативно впливали на розвиток тваринництва. Саме із-за цих обставин нами обрано зміни, що відбулись у наявності поголів'я сільськогосподарських тварин, 3 одного боку, та виробництво продукції тваринного походження, з іншого. Нами не приділено належної уваги дослідження основних причин, що призвели до негативних наслідків розвитку галузі. Ми на ці проблеми у фрагментарній формі звернули увагу, залишаючи ці дослідження наступним науковцям.

Таким чином, враховуючи вищесказане, суть проблеми даного дослідження полягає в тому, щоб проаналізувати наслідки впливу реформуючих процесів на стан розвитку тваринництва. При цьому нами обрано основні складові функціонування тваринницьких галузей, а саме: наявність поголів'я сільськогосподарських тварин та виробництво тваринницької продукції. Ці показники є надважливими та складають основу розвитку галузі і тому їх обрано за основу, що формує суть поставленої проблеми.

Аналіз останніх досліджень $і$ публікацій. Детальний аналіз останніх досліджень, його результати відображені у працях цілої плеяди як відомих дослідників, так і тих хто тільки почав займатися розв'язанням проблем розвитку галузей аграрного виробництва взагалі і його важливою складовою - тваринництва зокрема. У цій публікації не будемо поіменно перераховувати імена цих науковців. Вони відомі як тим, хто займається тваринництвом, так і тим, хто проявляє інтерес до розвитку тваринницьких галузей. Однак звернемо увагу на стан розвитку тваринницьких галузей 3 врахуванням фактору часу, який вплинув на такий стан. Отож, науковці у більшій мірі акцентували увагу на дослідженні вищесказаних проблем на рівні держави і менше звертали увагу на регіональний рівень. Одночасно зауважимо, що регіональний рівень $\epsilon$ основою розвитку будь-яких галузей національного господарства. Саме ці особливості враховано нами при проведені досліджень за обраною темою.

Постановка завдання. Метою даної публікації є дослідження наслідків реформуючих процесів, що відбулись в кінці XX і на початку XXI століть у розвитку тваринництва Львівщини. При цьому ще раз зазначимо, що при дослідженні вищесказаних проблем ми акцентували основну увагу на цифрові зміни у наявності поголів'я сільськогосподарських тварин та обсяги виробництва продукції тваринництва. Дію чинників, які обумовили негативні впливи на розвитку галузі, передбачено дослідити і проаналізувати у наступних публікаціях.

\section{Матеріал і методи досліджень}

Для реалізації поставленої мети нами використано нормативно-правові документи, статистичні матеріали, результати досліджень науковців, різні методи наукових досліджень. серед яких розроблений автором діалоговий метод дослідження. Його суть полягає в тому, що ми формуємо питання, відповіді на які знаходимо в рекомендованому джерелі (у нашому випадку це статистичний збірник). Саме такий підхід дозволяє більш глибше проникати в суть досліджуваних проблем і глибше їх аналізувати. Застосування цього методу проілюстровано при розкриті суті окремих категорій.

\section{Результати та їх обговорення}

Епохальні зміни у всіх сферах суспільних відносин обумовили перехід від однієї системи господарювання (соціалістичної) до іншої, яка була розвинена i діяла у передових країнах світу (ринкова). Досить також відзначити, що в умовах колишньої соціалістичної системи ведення господарської діяльності діяла адміністративно-командна форма управління. Ïї основою були “адміністративно-командні методи управління", які в економічній літературі трактуються, як “сукупність форм і методів управління суспільством, згідно з якими діяльність людей стимулюється переважно засобами адміністративного примусу, а всі фази управлінського циклу - рішення, організація виконання, контроль за виконанням рішення - ініціюються та здійснюються засобами жорсткого централізму, обмеженням процесів самоврядування на всіх рівнях" (Slipushko, 1999). Ринкова економіка характеризується іншими ознаками. С. В. Мочерний дав таке визначення цьому виду економіки: “Економіка ринкова 
- капіталістична економічна система, заснована на індивідуальних формах приватної власності, передусім капіталістичної, вільній грі ринкових сил (вільній конкуренції, вільному ціноутворенні, стихійному переливанні капіталу тощо)" (Моchernyj, 2000). Термін ринкова економіка ввів у використання А. Сміт (17231790).

Ось в таких діаметрально протилежних системах розвивалися різні системи функціонування суспільних відносин у світовому просторі. Перша система базувалася i здійснювалася "засобами жорсткого централізму, обмеженням процесів самоврядування на всіх рівнях", а друга - “заснована на індивідуальних формах приватної власності... вільній грі ринкових сил (вільній конкуренції, вільному ціноутворенні, стихійному переливанні капіталу тощо)". Друга система випробування часу доказала свою життєздатність, а перша проілюструвала досягнення тимчасових зрушень і досягнень, після чого виявилася недієздатною в умовах розвитку суспільних відносин взагалі і важливою їх складовою, особливу сферу виробничої діяльності, зокрема.

3 погляду теорії і практики проведення наукових досліджень, ці роботи слід починати із з'ясування суті окремих категорій, які мають пряме або опосередковане значення при їх здійсненні. Враховуючи саме ці архіважливі умови нами розглянуто суть основних категорій, що їх трактують певним чином статистичні органи.

\section{Таблиця 1}

Суть окремих категорій що визначені у статистичному збірнику Львівської області за 2019 рік

\begin{tabular}{|c|c|c|}
\hline $\begin{array}{l}\text { № } \\
\text { П/ח }\end{array}$ & Питання, сформовані нами & Відповіді із вищевказаного статистичного збірника \\
\hline 1 & $\begin{array}{l}\text { Що розуміється під поняттям } \\
\text { “підприємство”? }\end{array}$ & $\begin{array}{l}\text { Суб’єкт господарювання, який має право юридичної особи, або відокремле- } \\
\text { ний підрозділ юридичної особи, що здійснює систематичну виробничу діяль- } \\
\text { ність у галузі сільського господарства }\end{array}$ \\
\hline 2 & $\begin{array}{l}\text { Куди відносять фермерські } \\
\text { господарства? }\end{array}$ & До складу підприємств включають також фермерські господарства \\
\hline 3 & $\begin{array}{l}\text { Що представляють собою } \\
\text { господарства населення? }\end{array}$ & $\begin{array}{l}\text { Домогосподарства, що здійснюють сільськогосподарську діяльність як } 3 \\
\text { метою самозабезпечення продуктами харчування, так і } 3 \text { метою виробництва } \\
\text { товарної сільськогосподарської продукції }\end{array}$ \\
\hline 4 & Що включається у цю категорію? & $\begin{array}{l}\text { Ця категорія включає домогосподарства у сільській місцевості, міських насе- } \\
\text { лених пунктах, а також фізичних осіб суб'єктів підприємницької діяльності, } \\
\text { які проводять свою діяльність у галузі сільського господарства }\end{array}$ \\
\hline 5 & $\begin{array}{l}\text { Що характеризує показник про } \\
\text { кількість сільськогосподарських } \\
\text { тварин? }\end{array}$ & $\begin{array}{l}\text { Це показник, що характеризує наявність сільськогосподарських тварин пев- } \\
\text { ного виду (загальну або за статево-віковими групами) станом на звітну дату }\end{array}$ \\
\hline 6 & $\begin{array}{l}\text { Що включається у показники } \\
\text { виробництва сільськогосподар- } \\
\text { ської продукції: }\end{array}$ & \\
\hline & $\begin{array}{l}\text { м’яса сільськогосподарських тва- } \\
\text { н }\end{array}$ & $\begin{array}{l}\text { Загальна забійна маса (м’ясо, жир-сирець, харчові субпродукти) сільськогос- } \\
\text { подарських тварин, яка отримана як при реалізації на забій (товарний забій), } \\
\text { так і при внутрішньогосподарському забої тварин на м'ясо }\end{array}$ \\
\hline & валовий надій молока усіх видів & $\begin{array}{l}\text { Загальний обсяг фактично надоєного молока від корів усіх порід, буйволиць, } \\
\text { овець і кіз, кобил, інших маток сільськогосподарських тварин }\end{array}$ \\
\hline- & яйця від птиці свійської усіх видів & $\begin{array}{l}\text { Загальна кількість яєць, які отримані від усіх видів свійської птиці, уключаю- } \\
\text { чи втрачені через бій, псування тощо, а також витрачені для виведення моло- } \\
\text { дняку (інкубація) квочками або в інкубаторі. }\end{array}$ \\
\hline 7 & $\begin{array}{l}\text { Що не включається у валове } \\
\text { виробництво яєць }\end{array}$ & $\begin{array}{l}\text { Яйця, куплені або одержані на стороні для інкубації та інших потреб у вироб- } \\
\text { ництво яєць птиці свійської усіх видів не входять }\end{array}$ \\
\hline 8 & $\begin{array}{l}\text { Як визначається середній річний } \\
\text { надій молока від однієї корови? }\end{array}$ & $\begin{array}{l}\text { Співвідношення обсягу виробництва коров’ячого молока до наявної кількості } \\
\text { корів (без корів на відгодівлі, м’ясного стада, а також корів, призначених для } \\
\text { групового та підсосного утримання телят) на початок року }\end{array}$ \\
\hline
\end{tabular}

Джерело: статистичний щорічник Львівської області за 2019 рік

Зібрана і оброблена інформація з використанням діалогового методу дослідження представлена в таблиці 1. Погоджуючись із вищенаведеними твердженням про ті чи ті категорії все-таки вважаємо, що слід дещо уточнити трактування щодо визначення, середньорічного надою молока на одну корову, особливо для витрат молока на підсосне утримання телят.

У таблиці 2 представлено цифрову інформацію щодо наявності поголів'я різних видів сільськогосподарських тварин у господарствах Львівщини за період 1990-2018 pp. (закінчення епохи соціалістичного господарювання і наступними роками, в яких формувалися і розвивалися процеси ринкової економіки). При цьому зауважимо, що нами у таблиці 2 представлена і проаналізована інформація як по всіх категоріях господарств, так і в розрізі окремих форм господарювання. Таке діалектичне поєднання загального та індивідуального дає можливість більш глибше вникнути у суть досліджуваних явищ у розвитку тваринницьких галузей.

Отож, такий методологічний підхід дозволяє визначити, як реформуючі процеси вплинути на зміну пого- 
лів’я всіх видів сільськогосподарських тварин на протязі переходу від адміністративно-командної системи управління господарською діяльністю суб'єктів господарювання до використання механізмів ринкової економіки. Загальною закономірністю цих процесів $є$ те, що вони обумовили значне скорочення поголів'я сільськогосподарських тварин у 2019 р. у порівнянні з даними 1990 р. і 2018 р. (за виключенням поголів'я свійської птиці, показники якої збільшився у 2019 р. у порівнянні з 2018 р. на 8,8 \%).
Дещо інші закономірності і тенденції спостерігаються у зміні поголів'я сільськогосподарських тварин в окремих формах господарювання. Так, зокрема в аграрних підприємствах відбулись процеси зменшення поголів'я тварин різних їх видів, за виключення поголів'я свиней (поголів'я цих тварин зросло на 14,6 \% при порівнянні з даними за 2019 р. $з$ даними за 1990 р.). При порівнянні даних за 2019 р. із даними 2018 р., то ситуація дещо змінилася, однак тенденції майже не зазнали змін.

Таблиця 2

Наявність сільськогосподарських тварин у господарствах Львівщини, на кінець року тис. голів

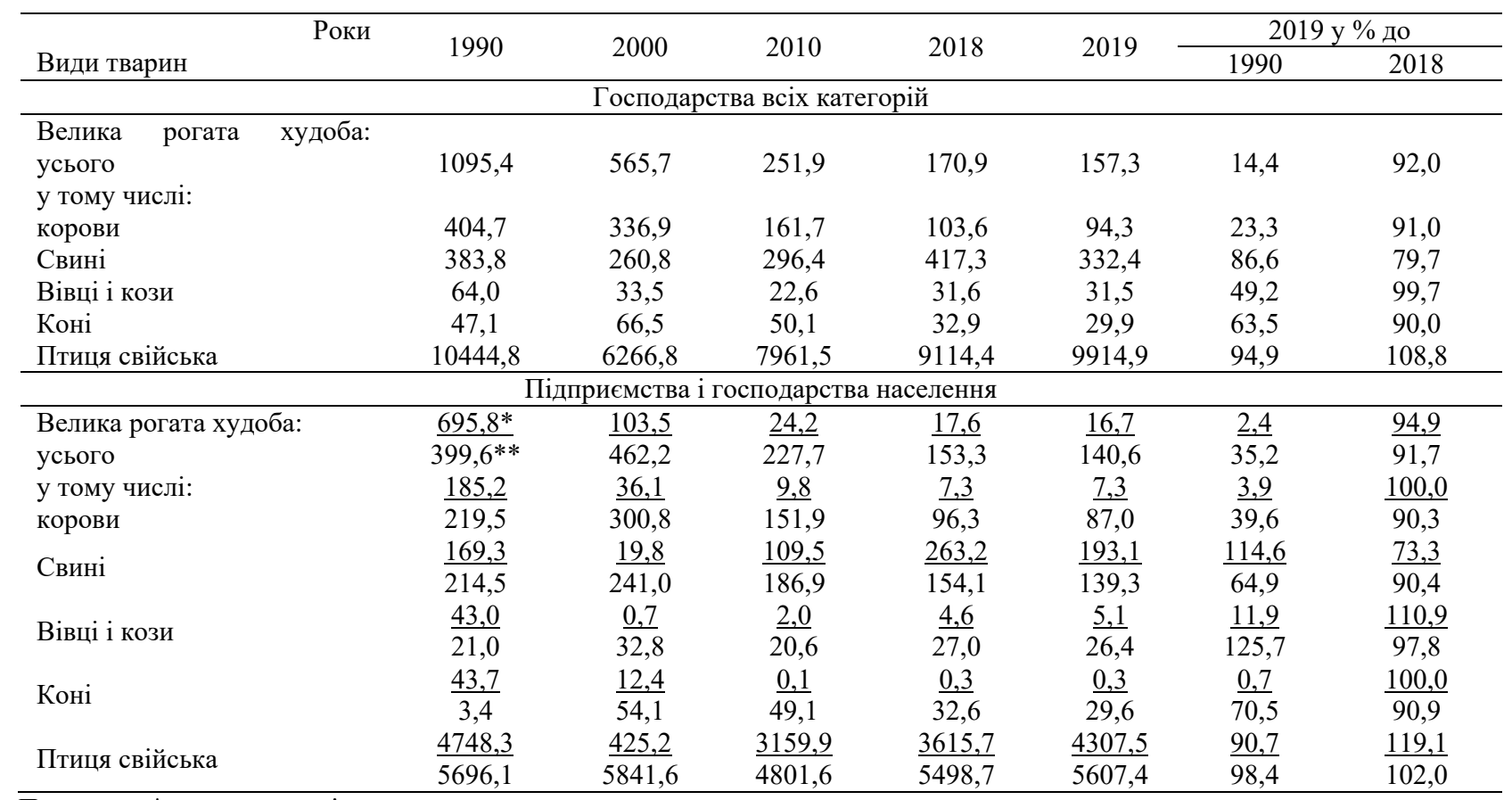

Примітки: *чисельник - підприємства;

**знаменник - господарства населення.

Джерело: статистичний щорічник Львівської області за 2019 рік

Таким чином, одержані результати дослідження дають підстави стверджувати, що перехід від адміністративно-командної системи господарювання до ринкової економіки супроводжувався в минулому і супроводжується в сучасних умовах значним скороченням поголів'я сільськогосподарських тварин. У цих умовах цілком закономірно постає питання, а в якому напрямі необхідно формувати наявність тварин: повертатися до дореформеного періоду (1990р.), чи дотримуватися рівня 2019 р.? 3 нашого погляду слід не дотримуватися ні першого, ні другого вектору руху, а за допомогою використання економіко-математичних методів розрахувати найбільш оптимальним варіант. Адже саме за допомогою цих методів можливо розрахувати найбільш оптимальне поголів'я тварин 3 врахуванням наявних умов розвитку як внутрішнього, так і зовнішнього характеру. Можливості реалізації такого підходу є у кожного господарюючого суб'єкта у Львівської області. Отож, розв'язання назрілих проблем щодо розрахунку наявності найбільш оптимальної кількості сільськогосподарських тварин у кожному господарському формуванні є. Їх тільки необхідно якісно використати для раціонального ведення тваринницьких галузей. Одночасно зауважимо, і це слід враховувати управлінським працівникам і спеціалістам, що важливо не тільки застосувати існуючі методи в тих чи тих розрахунках, але домогтися найбільш раціонального використання одержаних розрахунків. Це завдання, на перший погляд, легко сформувати i довести до найбільш раціонального використання одержаних розрахунків керівниками і спеціалістами у практичних цілях. Однак, як показує практика, значно важче реалізувати напрацьовані розробки безпосередньо у практичних умовах. Проте, попри всі труднощі, наявні проблеми слід аналізувати і розв'язувати на різних рівнях аграрного виробництва.

Результати дослідження другої складової наших завдань, а саме: аналіз виробництва продукції тваринництва господарськими формуваннями Львівщини як у загальному вираженні, так і в розрізі окремих господарських формувань, представлені в таблиці 3 . Деталізуючи результати дослідження, можна у повній мірі стверджувати, що загальні тенденції розвитку реформуючих процесів збереглися із незначним від- 
хиленням. Тобто зміни відбулись, однак закономірності залишилися без змін. Одночасно зауважимо, що найбільш конкурентною галуззю по відношенню до змін, що відбулись, є птахівнича галузь, а найбільш негативною до змін виявилось скотарство. Обсяг продукції цієї галузі у 2019 р. в порівнянні з 1990 р. скоротився більш, ніж наполовину.

Неабиякий інтерес щодо виробництва тваринницької продукції господарськими формуваннями Львівщини представляють показники ii продукування окремими групами господарств, а саме: підприємст- вами та господарствами населення. Перша група відноситься до крупних господарських формувань, а друга - до дрібних форм господарювання. Діяльність підприємств за аналізуючий період характеризується значними спадами виробництва тваринницької продукції за виключенням продукування м'яса свинини і птиці. Щодо господарств населення, то слід відзначити, що показники виробництва продукції тваринництва є більш стабільнішим за обсягами та динамічнішими за змінами на протязі аналізуючих років.

\section{Таблиця 3}

Виробництво продукції тваринництва за категоріями господарств Львівщини, тис. т

\begin{tabular}{|c|c|c|c|c|c|c|c|}
\hline \multirow[b]{2}{*}{ Види продукції } & \multirow{2}{*}{1990} & \multirow{2}{*}{2000} & \multirow{2}{*}{2010} & \multirow{2}{*}{2018} & \multirow{2}{*}{2019} & \multicolumn{2}{|c|}{2019 у \% до } \\
\hline & & & & & & 1990 & 2018 \\
\hline \multicolumn{8}{|c|}{ Господарства всіх категорій } \\
\hline $\begin{array}{l}\text { М'ясо (у забійній масі) } \\
\text { у тому числі: }\end{array}$ & 180,9 & 68,4 & 115,1 & 131,3 & 130,0 & 71,9 & 99,0 \\
\hline яловичина та телятина & 91,2 & 34,8 & 33,1 & 25,1 & 24,9 & 27,3 & 99,2 \\
\hline свинина & 50,3 & 23,3 & 37,5 & 50,3 & 47,8 & 95,0 & 95,0 \\
\hline м'ясо птиці & 37,8 & 8,9 & 47,6 & 53,8 & 55,3 & 146,3 & 102,8 \\
\hline Молоко & 1083,9 & 1032,0 & 656,2 & 506,7 & 480,9 & 44,4 & 94,9 \\
\hline Яйця, млн. шт. & 728,6 & 465,9 & 576,8 & 561,5 & 581,1 & 80,0 & 103,5 \\
\hline \multicolumn{8}{|c|}{ Підприємства і господарства населення } \\
\hline \multirow{2}{*}{ М’ясо (у забійній масі) } & $\underline{111,3^{*}}$ & $\underline{6,7}$ & $\underline{51,9}$ & $\underline{77,0}$ & $\underline{76,6}$ & $\underline{68,8}$ & 99,5 \\
\hline & $69,6^{* *}$ & $\overline{61,7}$ & $\overline{63,2}$ & $\overline{54,3}$ & 53,4 & 76,7 & 98,3 \\
\hline у тому числі: & $\underline{83,5}$ & $\underline{5,7}$ & $\underline{2,4}$ & $\underline{1,6}$ & $\underline{1,5}$ & $\underline{2,2}$ & $\underline{93,8}$ \\
\hline яловичина та телятина & $\overline{7,7}$ & $\overline{29,1}$ & $\overline{30,7}$ & $\overline{23,5}$ & $\overline{23,4}$ & $\overline{30,3}$ & $\overline{99,6}$ \\
\hline \multirow{2}{*}{ свинина } & $\underline{10,2}$ & $\underline{0,5}$ & $\underline{10,7}$ & $\underline{30,2}$ & $\underline{28,8}$ & 282,4 & $\underline{95,4}$ \\
\hline & $\overline{40,1}$ & $\overline{22,8}$ & $\overline{20,8}$ & $\overline{20,1}$ & $\overline{19,0}$ & $\overline{47,4}$ & $\overline{94,5}$ \\
\hline \multirow{2}{*}{ М'ясо птиці } & $\underline{16,8}$ & $\underline{0,4}$ & $\underline{38,8}$ & $\underline{45,2}$ & $\underline{46,3}$ & 275,6 & $\underline{102,4}$ \\
\hline & $\overline{21,0}$ & $\overline{8,5}$ & $\overline{8,8}$ & $\overline{8,6}$ & $\overline{9,0}$ & $\overline{42,8}$ & $\overline{104,7}$ \\
\hline \multirow{2}{*}{ Молоко } & $\underline{588,1}$ & $\underline{66,0}$ & $\underline{22,9}$ & $\underline{28,9}$ & 29,6 & $\underline{5,0}$ & $\underline{102,0}$ \\
\hline & 495,8 & $\overline{966,0}$ & 633,3 & 477,8 & 451,3 & 91,0 & 94,5 \\
\hline \multirow{2}{*}{ ЯйцЯ, млн. шт. } & 357,5 & 55,3 & 136,0 & 56,7 & 54,1 & 15,1 & 94,9 \\
\hline & 371,1 & 410,6 & 440,8 & $\overline{504,8}$ & $\overline{527,0}$ & 142,0 & 104,4 \\
\hline
\end{tabular}

Примітки: *чисельник - підприємства;

** знаменник - господарства населення.

Джерело: статистичний щорічник Львівської області за 2019 рік

\section{Висновки}

На основі проведених досліджень щодо співвідношення поголів'я сільськогосподарських тварин i виробництва продукції тваринництва господарствами Львівщини на даних етапах можна констатувати наступне: перехід від адміністративно-командних методів управління господарською діяльністю підприємств до механізмів ринкової економіки відбулись значні зміни у веденні тваринництва, а саме: скорочення поголів'я тварин, з одного боку, та зменшення обсягів виробництва основних видів продукції тваринництва 3 іншого; крупні аграрні формування в більшій мірі зазнали руйнацій своєї господарської діяльності, ніж дрібні господарства населення. В сучасних умовах розвиваються процеси щодо стабілізації функціонування організаційно-господарських структур аграрного виробництва. При цьому важливо не протиставляти діяльності крупних і дрібних форм господарювання, а найбільш оптимально поєднувати їх інтереси та можливості; для відновлення і стабілізації розвитку тваринництва необхідно, у першу чер- гу, більш широко і масштабне використовувати економічні механізми, що $є$ характерними для функціонування ринкової економіки. При цьому важливим $є$ продовження проведення наукових досліджень 3 концентрацією уваги на причини, що обумовили кризові явища у тваринництві. Одержані результати слід використовувати у практичній діяльності керівників і спеціалістів аграрного виробництва.

Перспективи подальших досліджень. Одержані результати досліджень відтворили основні закономірності розвитку тваринництва Львівщини у період реформуючих процесів, що відбувалися в період 1990-2019 рр. $з$ концентрацією уваги на зміни поголів'я сільськогосподарських тварин та виробництва тваринницької продукції. Нами фактично встановлено закономірності і тенденції змін цих показників, але не в повній мірі приділено увагу деталізації причин, що обумовили їх розвиток. Саме із-за цих обставин виникає об'єктивна необхідність продовження подальших досліджень за обраною темою як у сучасних умовах, так і на перспективу. 


\section{References}

Galanec', V., \& Galanec', V. (2015). Vidrodzhennja tvarynnyctva V Ukrai'ni. Visnyk L'vivs'kogo nacional'nogo agrarnogo universytetu: ekonomika APK, 22(1), 164-171 (in Ukrainian).

Gospodars'kyj kodeks Ukrai'ny [tekst] chynne zakonodavstvo Ukrai'ny zi zminamy ta dopovnennjamy stanom na 3 veresnja 2014 roku:(vidpovidaje oficijnomu tekstovi). K.: "Centr uchbovoi' literatury", 2014 (in Ukrainian).

Grymak, A. (2019). Do pytannia otsinky tendentsii i koniunktury rynku miasnoho skotarstva. NV LNU veterynarnoi medytsyny ta biotekhnolohii. Seriia: Ekonomichni nauky, 21(93), 13-16. doi: 10.32718/nvlvet-e9303 (in Ukrainian).

Hloušková, Z., \& Lekešová, M. (2020). Farm outcomes based on cluster analysis of compound farm evaluation. Agric. Econ. - Czech, 66, 435-443. doi: 10.17221/273/2020-AGRICECON.

Mochernyj, S. V. (2000). Ekonomichna encyklopedija: U tr'oh tomah. T.1. K.: Vydavnychyj centr "Akademij" (in Ukrainian).

Myniv, R. (2019). Suchasni tendentsii rozvytku miasnoho tvarynnytstva Ukrainy $\mathrm{v}$ umovakh yevrointehratsii.
NV LNU veterynarnoi medytsyny ta biotekhnolohii. Seriia: Ekonomichni nauky, 21(92), 3-8. doi: 10.32718/nvlvet-e9201.

Osei-Amponsah, R., Kwaku Asem, E., \& Yeboah Obese, F. (2020). Cattle crossbreeding for sustainable milk production in the tropics. International Journal of Livestock Production, 11(4), 108-113. doi: 10.5897/IJLP2020.0717.

Shulskyi, M. (2017). Tendentsii vyrobnytstva ahrarnoi produktsii subiektamy hospodariuvannia Lvivshchyny. NV LNU veterynarnoi medytsyny ta biotekhnolohii. Seriia: Ekonomichni nauky, 19(81), 79-83. doi: 10.15421/nvlvet8113 (in Ukrainian).

Slipushko, O. M. (1999). Politychnyj i finansovo ekonomichnyj slovnyk. K.: Krynycja (in Ukrainian).

Střeleček, F., Lososová, J., \& Kvapilík, J. (2004). Development of livestock in numbers and structure from the regional and administrative aspect. Agric. Econ. Czech, 50, 47-58. doi: 10.17221/5166-AGRICECON.

Zbars'kyj, V. K. (2014). Formy gospodarjuvannja na seli. Innovacijna ekonomika, 2(2), 45-52 (in Ukrainian).

Zymovina, S. (2020). Statystychnyj shhorichnyk L'vivs'koi' oblasti. Chastyna 1. L'viv (in Ukrainian). 